\title{
IDEOLOGÍAS LINGÜÍSTICAS: DESCAPITALIZACIÓN FANONIANA DE LOS ANDALUCES ${ }^{1}$
}

\section{LINGUISTIC IDEOLOGIES: ANDALUSIANS FANONIAN DECAPITALIZATION}

\author{
Ígor Rodríguez-Iglesias ${ }^{2}$ \\ Universidad de Huelva \\ igor.rodriguez@dfesp.uhu.es
}

\begin{abstract}
Resumen:
En este trabajo, se presenta la relación de fuerzas del mercado lingüístico de Bourdieu en el marco de la dicotomía zonas del ser/zonas del no-ser de F. Fanon. A partir de un estudio etnográfico sobre descapitalización de hablantes andaluces, se relaciona toda una ideología lingüística con una jerarquía global de inferiorización, en la que la lengua es un marcador. De este modo, la desvalorización de la variedad lingüística de un grupo por parte de otro grupo se explica a partir de una ideología de dominación con bases históricas y no como un hecho aislado, producto de las características inherentes de la variedad y el grupo inferiorizados y desvalorizados.
\end{abstract}

Palabras clave: mercado lingüístico, descapitalización, inferiorización, Andalucía, dominación.

\begin{abstract}
This paper deals with Bourdieu's relations of power (linguistic market) and Fanon's Zone of Being and non-Being. The article is based on recent ethnographic sociolinguistic research in Andalusia, south of Spain. In this paper, I explore ways in which the decapitalisation of Andalusian speakers is part of a global hierarchisation of inferiorization. In this way, the language is a marker. A group's devalued variety of language in the linguistic market is explained as ideology of domination with historical basis. Therefore, it is not a product of features of the no-legitimate language.
\end{abstract}

Keywords: linguistic market, decapitalisation, inferiorization, Andalusia, domination.

Recibido: 4/10/2015

Aceptado: 10/12/2016

\footnotetext{
${ }^{1}$ Investigación del área de Socialización lingüística. Código: Grupo de investigación: Bioling HUM792. Universidad de Huelva, España.

${ }^{2}$ Profesor del Área de Lengua de Española del Departamento de Filología e investigador del Grupo de Investigación HUM972 de la Universidad de Huelva.
} 


\section{Introducción}

El artículo que aquí se presenta versa sobre la discriminación lingüística, sobre los prejuicios lingüísticos. Si existe prejuicio y/o discriminación es porque los agentes sociales que conforman los grupos otorgan un valor, en relación con un mercado, a toda producción lingüística (Bourdieu, 2008: 50), por lo que el prejuicio y la discriminación, en relaciones de dominación, no son sino dos de sus consecuencias habituales, aunque extremas.

Este artículo presenta un análisis de la lógica jerarquizante a que responden tales prácticas sociales (incluidas las discursivas) y lo hace desde tres perspectivas totalmente complementarias: el área de conocimiento de las ideologías lingüísticas (aportación de la Antropología Lingüística norteamericana), la Sociolingüística Crítica y el giro decolonial, aportación crítica de diversos pensadores de campos diversos de Latinoamérica. En la última parte del artículo se presenta una discusión a partir de una etnografía realizada con hablantes andaluces, cuyas experiencias dan cuenta de su descapitalización como hablantes en campos simbólicos donde la palabra es pertinente, especialmente el mediático (y otros, como el educativo, donde la descapitalización se manifiesta de una forma más implícita).

\section{Las etiquetas ideologías lingüísticas, descapitalización y hablante andaluz}

La etiqueta ideologías lingüísticas, así en plural, nos remite a dos cuestiones: por un lado, al "área de investigación” (Woolard 15) que surge en la antropología lingüística norteamericana, que se desarrolla independientemente de una lingüística 'disidente' o "protestante" (Joseph y Taylor 2), una lingüística crítica, en definitiva. De otro lado, la etiqueta ideologías lingüísticas apela a las representaciones, explícitas o no, que "interpretan la relación entre la lengua y los seres humanos en el mundo social" (Woolard 19). Existen, no obstante, diversas concepciones acerca de qué son las ideologías lingüísticas (Woolard y Schieffelin 57):

- Con énfasis en la estructura lingüística: "Sets of beliefs about language articulated by users as a rationalization or justification of perceived language structure and use" (M. Silverstein).

- Con énfasis en lo social: "Self-evident ideas and objectives a group holds concerning roles of language in the social experiences of members as they contribute to the expression of the group" (S. B. Heath). Y "the cultural system 
of ideas about social and linguistic relationships, together with their loading of moral and political interests" (J. Irvine).

- Una definición general: "Shared bodies of common sense notions about the nature of language in the world" (A. Rumsey).

El área de las ideologías lingüísticas abarca tres líneas de reflexión académicas (Woolard 20): Antropología lingüística, Sociolingüística (crítica) y sociología del lenguaje, y Estudios críticos de los discursos, incluidos los de la propia lingüística (y la filología).

La otra etiqueta, descapitalización, hace referencia a los hablantes, a la manera en que su capital simbólico es desprovisto de la legitimidad ostentada con relación a un mercado. Tomamos este término del trabajo desarrollado por L. Martín Rojo y sus colaboradores del grupo MIRCo, en centros escolares en la Comunidad de Madrid, en el ámbito de la sociolingüística etnográfica crítica (véase Martín Rojo, Constructing 57) ${ }^{3}$.

Se podría decir que nuestro trabajo pivota sobre estas tres líneas: 1) parte de entender cómo los grupos sociales tienen diversas ideologías lingüísticas, esto es, portan conjuntos de representaciones sobre el lenguaje, los hablantes y sus prácticas discursivas (Irvine); 2) asume que "toda la estructura social está presente en cada interacción (y, a través, de ella en el discurso)" (Bourdieu, Significa 50-51), "les produccions discursives com el procés mateix d'estructuració de la societat (i no la manifestació d'unes estructures o sistema)" (Pujolar 13) ${ }^{4}$, que "els usos lingüístics contribueixen a reproduir i a transformar les relacions socials i, especialment, les relacions de desigualtat entre grups socials definits per criteris de repertori lingüístic, classe social, gènere, sexualitat, edat, religió, raça o etnicitat" (Pujolar 5), y que "las relaciones de comunicación por excelencia, los intercambios lingüísticos, son también relaciones de poder simbólico en las que se actualizan las relaciones de fuerza entre los locutores o sus respectivos grupos" (Bourdieu, Significa 11-12); y 3) atribuye o imputa a los estudios de las lenguas y las ciencias del lenguaje su alta contribución, no exclusiva, a la misma ideologización de los conceptos con que se opera técnicamente y

\footnotetext{
${ }^{3}$ Gran parte del trabajo que desarrollo es deudor de las enseñanzas y observaciones de Luisa Martín Rojo (Universidad Autónoma de Madrid), mi primera directora de tesis doctoral, de cuyo grupo de investigación fui investigador en formación. Mi otra deuda es para con quienes la precedieron en su tutela doctoral: Antonio Benítez Burraco, Universidad de Huelva, y Ramón Grosfoguel, University of California, Berkeley.

4 "No diferencia, per tant, entre aspectes lingüístics i aspectes socials; per bé que sovint es fan distincions entre aspectes discursius o ideològics, per una banda, i qüestions materials, per l'altra, per la necessitat de reconèixer límits o condicions no intrínsecament discursius" (Pujolar 13).
} 
que se ponen a disposición de la sociedad, a través de una institución social de primer orden: la escuela (Bourdieu y Passeron, Herederos 54; Swartz, Culture 189). Una crítica, pues, a y desde las ciencias sociales, a su propia historiografía y al propio objeto. Nuestro trabajo forma parte del conjunto de estudios críticos del discurso, si tenemos en cuenta que "los Estudios del Discurso podrán definirse más específicamente como «críticos» si satisfacen uno o varios de los siguientes criterios, en los cuales «dominación» significa «abuso del poder social por parte de un grupo social»:

- Las relaciones de dominación se estudian primariamente desde la perspectiva del interés del grupo dominado y a favor de éste.

- Las experiencias de (los miembros de) los grupos dominados se emplean además como prueba para evaluar el discurso dominante.

- El estudio puede mostrar que las acciones discursivas del grupo dominante son ilegítimas.

- Pueden formularse alternativas a los discursos dominantes que coinciden con los intereses de los grupos dominados" (van Dijk, Discurso 26).

Hay un tercer elemento: los andaluces y las andaluzas. Tenemos ante nosotros a agentes sociales, miembros de un grupo definido cultural y lingüísticamente históricamente, en definitiva-, que lo es como tal, y, a la vez, agentes con un(os) capital(es) simbólico(s) linguiístico(s) (variedad andaluza) caracterizado(s). No se trata tanto de que intralingüísticamente este grupo tenga eso que se da en llamar "nivelación", asociado a un tipo de ideología lingüística específica y que tanto ha ocupado a estudiosos del lenguaje y la lengua en Andalucía -sirva como ejemplo Carbonero, Estudios, 31-45-, sino de cómo otro grupo externo (dominante) construye una representación sobre este grupo andaluz (ya veremos por qué su situación es de dominado). Esta construcción implica que el grupo dominante desvaloriza los capitales simbólicos del otro grupo, dominado, a partir de sobrevalorar sus propios capitales.

La noción de "speech community" es abandonada en la sociolingüística actual (Blommaert y Rampton, 5-6). Aquí hablamos de grupos, por su operatividad y por alejarnos de aquel concepto problemático hoy. Este manejo de grupo como herramienta conceptual está más vinculado a la dicotomía dominante/dominado que a la idealización a la que remite aquel término que los primeros sociolingüistas usaron en los albores de la disciplina. Más adelante se discute esta cuestión. Por ahora, en nuestro estudio, grupo dominado es identificado con los y las hablantes andaluces y andaluzas en general, y 
grupo dominante con los grupos vinculados a las estructuras de dominio político, social, económico, etc. en España. No se trata, pues, de una cuestión geográfica, sino simbólica, aunque suele manifestarse en espacios geográficamente localizados: los territorios donde el grupo dominante se distribuye poblacionalmente. Como veremos, el centro y norte peninsular de España.

\section{Relación de fuerzas entre grupos. Zonas del ser y zonas del no-ser y línea abismal}

\subsection{Grupos dominantes/grupos dominados}

Estos grupos, dominante y dominado, están definidos en función de sus capitales lingüísticos, como conjunto de bienes que adquieren su valor con relación a un mercado (Bourdieu, Mercado 147). Y es aquí donde entra en juego la relación de fuerzas: ¿qué capital es el que impone los precios? o, dicho de otro modo, ¿qué capital tiene mayor valor? Esos capitales lingüísticos son recursos simbólicos que se definen en términos de representaciones socialmente compartidas por el intragrupo y que definen su valor social (cf. van Dijk, Ideología 183).

Estos grupos se posicionan entre sí y, en función de sus intereses, se defienden o legitiman contra otros (van Dijk, Ideología 205). "La posición y las relaciones de grupo son la contrapartida social más directa de las estructuras ideológicas, como es obvio en la conocida polarización entre el propio grupo y los otros" (ibid.). La exclusión de otros "define el abuso de poder y la dominación" (van Dijk, Ideología 206). Indica T. van Dijk que "las relaciones intergrupales son por lo general fundamentales en el desarrollo y sostenimiento de las ideologías y, a la inversa [...] las ideologías son la base de las prácticas sociales que implementa tales relaciones de grupo" (van Dijk, Ideología 217). "Grupos de diverso tipo [pues] (incluyendo aquí las clases) desarrollan ideologías de grupo, y lo hacen especialmente en estructuras sociales caracterizadas por el conflicto, la competencia y la dominación. [...] si existen 'clases dominantes', éstas también tendrán sus propias ideologías" (van Dijk, Ideología 227).

En el mercado lingüístico, descrito por Bourdieu (Mercado y Significa), se ponen de manifiesto relaciones de dominación, señaladas por Foucault (Defender, 45), tanto entre los propios grupos como entre sus miembros (Defender, 32), siempre en atención a la estructura social presente en el discurso y en la relación objetiva entre 
grupos con capitales linguiísticos diferentes, que subyace a la relación entre dos hablantes cualesquiera (Bourdieu, Significa 50-51).

La relación siempre es entre grupos de hablantes o sus miembros (Bourdieu, Significa 51), nunca entre las lenguas, pues estas no tienen existencia ontológica y no pueden per se mantener una relación. La metáfora (relación entre lenguas) no deja de ser una trampa ${ }^{5}$. El contacto lingüístico es contacto entre grupos humanos y aunque R. E. Hamel (Hamel, 65) abogue por mantener "viva la metáfora" siempre que se siga "guardando en mente la relación entre sujetos sociales y lenguas", considero que es momento de abandonar las metáforas, pues esa relación no siempre se guarda en mente. La relación de dominación la ejerce un grupo sobre otro, no una lengua. Además, el concepto de lengua para la sociolingüística y la lingüística críticas actuales está tan obsoleto como el de comunidad de habla, que veíamos antes (Blommaert y Rampton, 56) y que más adelante discutimos.

El foco de atención lo ponemos aquí sobre la relación entre grupos: grupo A frente a grupo B. Lo haremos con breves apuntes etnográficos, que suponen una particularización de la generalidad que, en términos operativos, nos es útil.

Aunque los rasgos del grupo descapitalizado estén asociados a lo que la lingüística llama 'diatópico', en terminología de Flydal (Cit. en Coseriu, 298), no se trata de una relación de fuerzas de grupos geográficos, sino de un grupo definido lingüísticamente con adscripción geográfica en conflicto frente a un grupo dominante, no necesariamente situado geográficamente, pero sí política e históricamente, y sujetos que reproducen las prácticas del grupo dominante en relación con el grupo o los grupos dominados, aun perteneciendo a éstos, por los motivos que concurran (bien porque se identifiquen, bien porque hayan sido adiestrados en este sentido, etc. -la primera razón, además, implica la segunda-). Es, pues, una dominación simbólica de lo que hablamos, que siempre “implica, por parte de los que la sufren, una especie de complicidad que no es sumisión pasiva a una norma externa ni adhesión libre a valores" (Bourdieu, Significa 29). La escuela (todos los niveles, incluyendo el superior) juega un papel fundamental en esta cuestión.

Como ya ha sido adelantado, nuestro grupo no-dominante en esta relación de fuerzas y definido geográficamente es el andaluz. El dominante es definido en términos

\footnotetext{
${ }^{5}$ El libro Languages in Contact (Weinreich), paradójicamente, constituye uno de los precedentes de la Sociolingüística. Weinreich toma el título de uno de los cursos que impartió en Columbia André Martinet, su director de tesis doctoral, que supone la base del libro de quien fuera a su vez director de tesis de W. Labov una década después (Fernández, 123).
} 
simbólicos más que geográficos, aunque se localice espacialmente, y es aquel cuyos capitales simbólicos lingüísticos corresponden o se acercan a la variedad castellana, legitimada por las diferentes instituciones sociales de dominación, como discutiremos. Toda relación de fuerzas en un esquema de dominación, de desigualdad, que define y actualiza las relaciones del sistema-mundo (Wallerstein, Análisis 136 y Después 29) ${ }^{6}$ y los grupos (Bourdieu, Significa 12), supone una jerarquía de superioridad e inferioridad, de minorización, de inferiorización y de legitimación por parte de determinados grupos (Grosfoguel, Racismo 93), lo que se ha simplificado, a efectos operativos, entre grupos dominantes/grupos dominados (van Dijk, Discurso 25).

\subsection{Zonas del ser y del no-ser. Línea abismal}

\section{B. de Sousa Santos indica que}

La epistemología occidental dominante fue construida a partir de las necesidades de la dominación capitalista y colonial y se asienta en lo que designo pensamiento abismal. Este pensamiento opera por la definición unilateral de líneas radicales que dividen las experiencias, los actores y los saberes sociales entre los que son visibles, inteligentes o útiles (los que quedan de este lado de la línea) y los que son invisibles, ininteligibles, olvidados o peligrosos (los que quedan del otro lado de la línea). Así, la realidad social es dividida en dos universos, el universo de «este lado de la línea» y el universo del «otro lado de la línea» (De Sousa Santos, Descolonizar 8).

Esta lógica define muy bien lo que el grupo dominante impone a través de todo su cuerpo de juristas del lenguaje (escuela, gramáticos, medios de comunicación, etc.): una lengua legitimada a la que atenerse y que capitaliza a los sujetos que tienen acceso a todas las características que este sistema impone como legítimos, desechando arbitrariamente (en el sentido de que no hay un causa objetiva) el resto de capitales lingüísticos (y simbólicos, en general), lo que da lugar a la discriminación, producto de este sistema de valores sobre el que se construye y se ha construido la epistemología occidental y occidentalizada ${ }^{7}$.

\footnotetext{
${ }^{6}$ I. Wallerstein define el sistema mundo moderno como "el sistema-mundo en el que ahora vivimos, el cual ha tenido sus orígenes en el siglo XVI en Europa y América. El sistema-mundo moderno es una economía-mundo CAPITALISTA" (2006: 136). "La economía-mundo capitalista es un sistema que incluye una desigualdad jerárquica de distribución basada en la concentración de ciertos tipos de producción (producción relativamente monopolizada, y por lo tanto de alta rentabilidad), en ciertas zonas limitadas" (2001: 29).

${ }^{7}$ Occidente es una construcción a partir de la invención epistémica de un Oriente, invención que es producto y acompaña a las prácticas imperialistas de Francia y el Imperio Británico en los siglos XVIII y XIX. En este sentido, el palestino E. Said fue el primero en llamar la atención sobre esta construcción, de tal modo que Oriente es "una visión política de la realidad cuya estructura acentuaba la diferencia entre lo familiar (Europa, Occidente, «nosotros») y lo extraño (Oriente, el Este, «ellos»). Esta visión, en cierto
} 
Es una característica muy propia de esa lógica que ha construido un conjunto de "aparatos disciplinarios [que] jerarquizan los unos con relación a los otros" (Foucault, Vigilar 186), lógica que para Dussel arranca en 1492 (Encubrimiento) y Grosfoguel (Racismo 50) remonta a la conquista castellana de Al Andalus.

La línea abismal es la que dividirá estos dos universos, no sólo a efectos claros de "esclavitud", en el mundo colonial, y "clases sociales", en la Europa preindustrial e industrial, sino a efectos epistémicos. La denuncia que hace J. C. Moreno Cabrera cuando dice que existe en determinados filólogos y lingüistas una "anteposición de la ideología a la ciencia" (Nacionalismo 186) está totalmente vinculada con esto, aunque no tal como lo plantea, pues la ciencia comporta una/s ideología/s. El problema es todo el sistema sobre el que está construido el conocimiento (véase Dussel Política), que, además de comportar una "herencia colonial”, refuerza la hegemonía del Norte global, como señala Lander (Conocimiento 53). De ahí, las propuestas para deconstruir el conocimiento occidental y occidentalizado, para repensarlo, incluyendo otras epistemologías, no sólo localizadas geográficamente, sino también social (otros grupos), étnica (otras culturas) o sexualmente (feminismo): Boaventura de Sousa Santos (Descolonizar), Enrique Dussel (Filosofía), Ramón Grosfoguel (Concepto), Nelson Maldonado-Torres (Coloniality), Yuderkis Espinosa, Diana Gómez y Karina Ochoa (Tejiendo) o Silvia Rivera Cusicanqui (Violencias) son buenos ejemplos de esto.

F. Fanon, desde su posición de "colonizado" y "negro" de la colonia frente a la Francia del blanco de la metrópoli, tuvo el acierto de anticipar, a mediados del siglo $\mathrm{XX}$, los dos lados de la línea abismal: la zonas del ser y el no-ser, en relación al racismo, la esclavitud y los pueblos colonizados. Sin embargo, como advierte, R. Grosfoguel (Racismo 94): "Para Fanon, ninguna de estas zonas es homogénea. Ambas zonas son espacios heterogéneos. Dentro de la zona del ser existen conflictos continuos

sentido, creó y luego sirvió a los dos mundos así concebidos. Los orientales vivían en su mundo, «nosotros» vivíamos en el nuestro". El adjetivo "occidentalizada" llama la atención sobre cualquier práctica, ideología, institución, etc. eurocéntricas (occidentalocéntricas) que, como es obvio, no tienen por qué ser europeas, pero sí funcionar respecto de su lógica en cualquiera de las formas en que el eurocentrismo se manifiesta: epistemología, política, economía, relaciones sociales e interpersonales, etc. De este modo, por ejemplo, una universidad, como el giro decolonial ha puesto de relieve, puede no estar en Europa y ser europeizante en su canon de pensamiento, como resultado del sistema-mundo moderno (Wallerstein, Análisis; Dussel, Filosofía 24). R. Grosfoguel explica, en este sentido, que "la epistemología eurocéntrica en las universidades occidentales está caracterizada no solamente por privilegiar el canon de pensamiento del hombre occidental (el género es apropósito), sino también por estudiar al 'otro' como objeto y no como sujeto que produce conocimiento, ocultando así la 'geo-política' y la 'corpo-política' del conocimiento mediante la cual los académicos e intelectuales blancos piensan" (Grosfoguel, Retos 14). Un sujeto puede ser no occidental, según la lógica construida a la que he aludido, y ser occidentalocéntrico, esto es, su pensamiento y acciones pueden ser y estar occidentalizados. 
entre lo que en la filosofía hegeliana se caracteriza como la dialéctica del «Yo»y el «Otro»", lo que indica que las zonas del ser están vinculadas a lo que llama Dussel (Filosofía 201) "clases opresoras", siendo el resto zonas del no-ser, las "clases populares" (ibid.), los grupos dominados, que hemos llamado así desde el inicio y que no están situados geográficamente en sí.

Quiere decir esto que no se trata de una relación de fuerzas la que se nos plantea en nuestro estudio entre el centro-norte peninsular (español) geográficos y la Andalucía geográfica, sino entre el centro y el norte peninsulares simbólicos y la Andalucía simbólica, que se actualiza tanto con relación a lo geográfico como a lo social. Esclarecedor será tener en cuenta que

Desde 1873 no existía ya en Andalucía, ni ha existido más tarde, ningún sector de la burguesía cuyos intereses fueran en determinados momentos contradictorios con los defendidos por la oligarquía centralista, cosa que sí ha sucedido en ocasiones en Cataluña y otros lugares (Moreno, Identidad 40).

Las zonas del ser corresponden con esos grupos burgueses, oligárquicos, y las del no-ser con el resto de la población, o si se prefiere, la línea abismal se sitúa entre estos grupos, con la advertencia que hacíamos más arriba de aquella complicidad no consciente por parte de los situados debajo de la línea. Esto no quiere decir que la lengua de las clases populares de Madrid o Castilla esté sometida a un proceso de ilegitimación y desvalorización respecto del mercado lingüístico en el que opera. Si lo es con Andalucía es porque hay todo un trasfondo histórico y filosófico-ontológico producto de la experiencia, de prácticas sociales perpetradas desde y a través de la inferiorización del otro, de su persecución y sometimiento y hasta su expulsión, no sólo geográfica, sino también ontológica. Grosfoguel (Racismo) identifica estas experiencias en la misma conquista castellana de Al Andalus: "La práctica de limpieza étnica del territorio andalusí produjo un genocidio físico y cultural contra musulmanes y judíos. Los judíos y musulmanes que se quedaron en el territorio fueron asesinados (genocidio físico) o forzados a convertirse al cristianismo (genocidio cultural)" (Grosfoguel, Racismo 39). Estas prácticas han seguido vigentes en el siglo XX, explícitas -como ya apuntamos en en otro lugar (Rodríguez Iglesias, Hybris 100)- durante la guerra que siguió al golpe militar de 1936 en España y la dictadura fascista que le continuó. Así lo apunta el historiador G. Jackson: 
El contraste entre la conducta militar en Andalucía y el Norte reflejaba sentimientos raciales muy profundos. En efecto, no es raro que españoles de las ideologías más diversas se refieran a los andaluces como gentes inferiores. (...) En Andalucía, los oficiales de carrera a menudo se comportaron como si estuvieran dedicados a una operación de exterminio químico. En el Norte miraban a sus enemigos como seres humanos. (Jackson, 248).

El filósofo español Ortega y Gasset publica antes su Teoría de Andalucía, que no son más que dos artículos en un diario madrileño en la década de 1920. Desde Madrid, desconocedor de la experiencia del ser andaluz, en Ortega se concentra una ontología del ser y del no-ser, este último el/la andaluz/a. Ni que decir tiene que todo lo que sigue son falacias sin fundamento:

"el andaluz lleva unos cuatro mil años de holgazán y no le va mal. [...] la holgazanería [...] ha hecho posible la deleitable y perenne vida andaluza. [...]. la famosa holgazanería andaluza es precisamente la fórmula de su cultura. [...] en vez de esforzarse para vivir, vive para no esforzarse, hace de la evitación del esfuerzo principio de su existencia. [...] Podrá en el andaluz ser la pereza también un defecto y un vicio; pero, antes que vicio y defecto, es nada menos que su ideal de existencia. [...]. la pereza como ideal y como estilo de cultura. [...] su pereza no excluye por completo la labor, sino que es más bien el sentido y el aire que adopta su trabajo. Es un trabajo inspirado por la pereza y dirigido hacia ella, que tiende, por tanto a ser en todo orden el mínimo, como si se avergonzase de sí mismo. [...] Reduce al mínimo la reacción sobre el medio porque no ambiciona más y vive sumergido en la atmósfera como un vegetal. [...] la existencia de la planta se diferencia de la animal en que aquella no reacciona sobre el contorno. Es pasiva al medio. [...] Diríase que en la vida andaluza, la fiesta, el domingo, rezuma sobre el resto de la semana e impregna de festividad y dorado reposo los días laborales. [...] El andaluz tiene un sentido vegetal de la existencia" (Ortega y Gasset, 109-113).

Ortega y Gasset no constituye un caso aislado. Su texto forma parte ya de una narrativa bien asentada en las décadas que le preceden. El historiador Salvador Cruz Artacho indica: "Atraso agrario, miseria, hambre, analfabetismo o incultura constituían tan solo algunos de los calificativos reiterados en muchos de los ejercicios de teorización sobre el ser y la condición de Andalucía que se materializaron en el cambio del siglo XIX al siglo XX" (Cruz 11), cuyo precedente teorizador lo constituye el conjunto de asertos de los románticos alemanes en términos similares (ibid.).

Esta desvalorización llega a nuestros días. No son pocas las declaraciones públicas de políticos foráneos del resto de España que traslucen esta ideología inferiorizadora y referida a la lengua. Valgan aquí dos ejemplos: 
- "Tiene un problema esta buena mujer y es que tiene un acento que parece un chiste, tiene un problema de comunicación, que se aturulla y hace un lío [...]. Yo que algunas veces cuando llamo a Córdoba y oigo desde algún hotel que me contestan y no acabo de entender, porque si no estás avezado en hablar en andaluz normalmente pues te cuesta, imagínate cuando además el problema es de comunicación siendo andaluza". Lo dijo en 2009 en una entrevista de radio la entonces diputada del Parlament catalán Monserrat Nebrera, del PP (a los pocos meses fue obligada a dimitir y abandonó ese partido), profesora de Derecho Constitucional en la Universitat Internacional de Catalunya, en referencia a la exministra andaluza Magdalena Álvarez, del entonces gobierno de José Luis Rodríguez Zapatero (PSOE).

- "Es floja, le falta cuajo y su acento la hace más apta para Dos Hermanas o Vélez-Málaga". Lo dijo el portavoz adjunto del PP en la Asamblea de Madrid, el parlamento regional de la Comunidad Autónoma de Madrid, Juan Soler. Fue en 2010 y se refería a una exministra andaluza del citado Gobierno del PSOE. Dos Hermanas es una localidad de la provincia de Sevilla y Vélez-Málaga otra población de la provincia de Málaga. Ambas provincias conforman, junto a otras seis, la Comunidad Autónoma de Andalucía.

Nuestra tesis se apoya en este pilar: de las citadas experiencias inferiorizadoras a lo largo de todo el periodo de la modernidad se derivan determinadas ideologías. Sin embargo, para que se den determinadas experiencias, éstas han de estar sustentadas por ideologías previas, productos de otras experiencias precedentes, que es a lo que apunta Grosfoguel (Racismo). Es por ello que discrepamos de Woolard en este punto. La antropóloga lingüística norteamericana sostiene que "las ideas acerca de lo que es o no una lengua 'real' han influido en las trascendentes decisiones tomadas sobre la civilidad e incluso humanidad de los otros, en particular sobre los sujetos de la dominación colonial en las Américas y más allá" (Woolard, Ideologías 39). Sostenemos, con Dussel (Encubrimiento) y Grosfoguel (Racismo), exactamente lo contrario: las decisiones tomadas sobre la civilidad e incluso humanidad de la otredad han influido sobre las ideas acerca de lo que es o no una lengua 'real'. Sobre la humanidad misma de otros pueblos se pregunta Fernández de Oviedo al poner un pie en lo que llamamos desde entonces América: “Son hombres los indios?” (Dussel, Filosofía 15) y no le preceden consideraciones acerca de sus lenguas. Su precedente inmediato es el propio Colón, que 
en su Diario de a bordo escribe: "Me pareció que ninguna secta tenían" (Colón, 93), en referencia a los habitantes del Caribe y al hecho de que, según el navegante italiano, carecían de religión. "Referirse a los indígenas como sujetos sin religión los saca aparte de la categoría de lo humano", según el filósofo puertorriqueño Nelson MaldonadoTorres (Cit. en Grosfoguel, Racismo 89).

Esta ontología de seres autosuperiorizados y de seres inferiorizados constituye el "exceso ontológico" del que habla el antropólogo colombiano Arturo Escobar, "que ocurre cuando seres particulares se imponen sobre otros" (Escobar 35). Este exceso ontológico precede a 1492, como apunta Grosfoguel (Racismo), y dará lugar tanto a prácticas de violencia en ambas orillas del Atlántico desde el siglo XVI y a teorizaciones sobre la otredad, incluidas las ideologías lingüísticas acerca de estos grupos, ahora inferiorizados. Los judíos y musulmanes son perseguidos, expulsados u obligados a convertirse al cristianismo. E incluso los descendientes de los convertidos fueron expulsados definitivamente a principios del siglo XVII. Sin embargo, no todos se fueron. El historiador Enrique Soria Mesa ha demostrado que

"A pesar de todas las expulsiones decretadas por la Corona, cientos o miles de familias moriscas se quedaron en tierras granadinas. A partir de $1614 \mathrm{y}$ hasta 1727 este conjunto poblacional pasó prácticamente inadvertido, escapando a cualquier control eclesiástico o civil, y desapareciendo de la documentación como por arte de magia. Se ocultaron casi del todo" (Soria Mesa 229).

Sobre la lengua, ya en el siglo XVI hay prohibiciones explícitas respecto del uso del árabe en Andalucía, cuyos territorios han sido conquistados por los castellanos cristianos desde el siglo XIII al XV, periodo de prácticas etnocidas (Grosfoguel, Racismo 39-40). Un ejemplo de prohibición lingüística lo constituye la orden de Felipe II a través de la Pragmática y declaración sobre los moriscos esclavos que fueron tomados en el Reyno de Granada y la orden que con ellos se ha de tener, publicada en 1573, donde se puede leer: "Prohibimos y defendemos que los dichos moriscos no puedan tener ni leer libros ni otras escrituras en lengua arábiga" (se da opción a que "se traduzcan en lengua castellana" las escrituras que "tocasen a su hacienda" (10), así como "prohibimos y defendemos que los dichos moriscos, allí hombres como mujeres, no puedan hablar ni hablen en lengua arábiga en sus casas ni fuera de ellas, ni escribir cartas memorias, ni otra cosa alguna en la dicha lengua". Las penas son explícitas: la 
primera condena conllevaba 30 días de cárcel; la segunda, 60 días; la tercera, cien azotes y cuatro años al remo en las galeras (11).

Las burlas a judíos y cristianos son muchas en la literatura del llamado Siglo de Oro español: "Ya desde el siglo XV aparecen parodias satíricas del habla de los moros, cuya continuación cómica y burlesca desarrollarán con brillantez Lope de Rueda, Quevedo, Góngora o Lope de Vega" (Fanjul 66).

Durante el siglo XVI, las anotaciones sobre el castellano de los andaluces ya apuntan en la dirección de la desviación, por notar una diferencia respecto de las hablas de Castilla. Por ejemplo, el humanista extremeño Benito Arias Montano explica en 1592 diversos fenómenos fonéticos constitutivos del andaluz por causa de "la negligencia e incuria o del vicio de la gente, y de la indulgencia de las madres" ("gentis vel negligentia et incuria, vel vitio et matrum indulgentia natum") (Arias Montano 495).

En 1535, el humanista manchego Juan Valdés criticaba en su Diálogo de la Lengua a al gramático andaluz Antonio de Nebrija de esta forma, relacionando su "tan poco cuidado" en su Vocabulario de 1494 por ser andaluz que resulta en "burla":

¿Por qué queréis que me contente? ¿Vos no veis que, aunque Librija era muy docto en la lengua latina, que esto nadie se lo puede quitar, al fin no se puede negar que era andaluz, y no castellano, y que escribió aquel su Vocabulario con tan poco cuidado que parece haberlo escrito por burla? Si ya no queréis decir que hombres envidiosos, por afrentar al autor, han gastado el libro (Valdés, Diálogo).

Para Valdés la lengua en Andalucía no es "tan pura" como en Castilla:

En que, dejando aparte la ortografía, en la cual muchas veces peca en la declaración que hace de los vocablos castellanos, en los latinos se engaña tantas veces que sois forzado a creer una de dos cosas: o que no entendía la verdadera significación del latín (y esta es la que yo menos creo) o que no alcanzaba la del castellano, y esta podría ser, porque él era de Andalucía, donde la lengua no está muy pura.

A lo largo de la obra, Valdés vuelve a referirse a Nebrija (Librija en su texto) en similares términos: "No me aleguéis otra vez para la lengua castellana el autoridad de Librija andaluz, que me haréis perder la paciencia” y "ya tornáis a vuestro Librija. ¿No 
os tengo dicho que, como aquel hombre no era castellano, sino andaluz, hablaba y escribía como en Andalucía, y no como en Castilla?".

Las ideologías lingüísticas se construyen desde prácticas sociales específicas y, como ya hemos apuntado, retroalimentan prácticas similares, que a su vez alimentan estas y otras ideologías, como las referidas a la civilidad, sobre la que apuntaba Woolard (supra).

No hay que irse muy lejos para ver cómo las ideologías lingüicidas también lo son etnocidas. No puede perderse de vista que las lenguas no tienen vida y su muerte no es más que una metáfora, que disfraza lo que realmente ocurre: la muerte de los pueblos, de las culturas. Desde la filología Gregorio Salvador (Lenguas) y Manuel Alvar (Hombre) -figuras destacadas en los estudios lingüísticos en España- realizan todo tipo de asertos de inferiorización sobre otros pueblos. Para G. Salvador, "el problema de la situación en México, tanto en Chiapas como en Oaxaca, es que hay todavía muchas lenguas" (p. 6), que, junto a las otras que no son las europeas expandidas por el colonialismo, considera "menores" (p. 8); se pregunta sobre "cómo van a ser todas las culturas iguales" (ibid.); sostiene que "el multilingüismo planetario es una desgracia" (ibid.) y culpa de la desigualdad al uso de estas lenguas no europeas y no a las condiciones creadas por el colonialismo: "La gran desgracia del continente africano, la multiplicidad de lenguas, el multilingüismo, que cada tribu hable su propia lengua" (p. 7). Manuel Alvar, por su parte, se refirió en estos términos a uno de los pueblos originarios de Abya Yala: "Si los yaguas se mantienen como yaguas es por un aislamiento del que deben salir, y deben salir para alcanzar dignidad humana" (Hombre 151), "porque un indígena sin más conocimientos que los del mal cuidar un pedazo de tierra será poco más que cualquiera de aquellos animales con los que convive, pero tampoco tendrá muchas más apetencias”.

Manuel Alvar se dedicó a la dialectología y la geografía lingüística y es conocido por sus estudios del andaluz. Sorprenden sus aseveraciones en este sentido acerca del andaluz: "es un caos en efervescencia, que no ha logrado establecer la reordenación del sistema roto" (Alvar, Lengua 31) o "unas hablas como éstas, muy diferenciadas de la lengua común, sirven para acentuar el sentido dialectal de las gentes que las emplean; más aún crean una autoafirmación de personalidad que les hace descuidar todo aquello que es dispar, y eso desde el catedrático de Universidad hasta el 
último bracero" (18). Este "caos", estas "hablas" no son lengua, no son "sistema" para Alvar porque, según indica, "el andaluz está desgajado de la lengua común porque todas las amarras que formaban la unidad han ido saltando violentamente rotas" $(31)^{8}$. Sorprenden estas aseveraciones respecto de los conceptos del estructuralismo lingüístico que sólo maneja en su nomenclatura y no es sus fundamentos. No sorprende si se pone en relación con lo sostenido respecto de otros pueblos no dominantes del mundo.

Puede advertirse que no usamos conceptos tradicionales de la sociolinguiística, como comunidad de hablantes, discutida por J. Blommaert y B. Rampton (Language), por ser deudora de conceptos en desuso en las ciencias sociales como nación o pueblo, incluido el propio concepto de lengua, que los procesos de globalización ponen cada vez más en cuestión (Blommaert, Sociolinguistics 132). Los sociolingüistas vienen contestando a esta idealización, que no es capaz de conciliar con la diversidad lingüistica, como ya habían puesto de relieve en 1982 Ferguson y en 1997 Leung, Harris y Rampton (Blommaert y Rampton, Language 6). Y no son los únicos:

Linguistics has traditionally privileged the structure of language, and treated language use as little more than a product/output generated by semantic, grammatical and phonological systems, which are themselves regarded either as mental structures or as sets of social conventions. But this commitment to system-in-language has been challenged by a linguistics of communicative practice, rooted in a linguistic-anthropological tradition running from Sapir through Hymes and Gumperz to Hanks (1996), Verschueren (1999) and Agha (2007). (Blommaert y Rampton, Language 6-7).

A desinventar las lenguas (título del libro del que son editores) nos invitan Makoni y Pennycook (Disinventing), ya tratada como prácticas y como mecanismo de dominación por Fairclough (Language) (cf. Wodak Language).

Es, por ello, que desde nuestro marco teórico no trabajamos con el fin de determinar si tal o cual grupo tiene tal o cual característica lingüística, porque sería deudor de los enfoques tradicionales e inmanentistas y, más que resolver los problemas sobre los que ponemos el foco, contribuirían a su expansión.

\footnotetext{
${ }^{8}$ Para una crítica a Alvar sobre el andaluz, léase J. C. Moreno Cabrera. El nacionalismo lingüístico. Una ideología destructiva. Barcelona: Península, 2008.
} 
Por lo tanto, nuestra atención se centra en los grupos y, sobre todo, a partir de la línea que los separa o, mejor, en que ellos mismos se separan, no necesariamente de manera mutua. Por ello, partimos de las prácticas discursivas y las experiencias sociales para luego, a partir de las mismas, construir un aparato teorético que nos permita afrontar tal problemática.

\section{Ideología lingüística y mercado lingüístico}

Es preciso tener en cuenta que "lo que circula en el mercado lingüístico no es la «lengua», sino discursos estilísticamente caracterizados” (Bourdieu, Significa 13), conformando un mosaico al que atenerse para la obtención de ganancias simbólicas.

Los discursos sólo reciben su valor (y su sentido) en relación con un mercado, caracterizado por una ley de formación de precios específica: el valor del discurso depende de la relación de fuerzas que se establece concretamente entre las competencias lingüísticas de locutores (Bourdieu, Significa 50).

Bourdieu (ibid.) explica que estas competencias lingüísticas son "capacidades de producción socialmente clasificadas" y como tales "caracterizan unidades de producción lingüística socialmente clasificadas". A su vez, son “capacidades de apropiación y apreciación [que] definen mercados también socialmente clasificados", contribuyendo "a determinar la ley de formación de precios en intercambios concretos", sometidos a una relación de fuerzas mayor, en ausencia, entre los grupos sociales, como indicamos más arriba.

Todo acto de habla, y en general toda acción, es una coyuntura, una concomitancia de series causales independientes: por un lado, las disposiciones, elaboradas socialmente, del habitus lingüístico, que implica cierta propensión a hablar y a decir determinadas cosas (interés expresivo) y cierta capacidad de hablar definida al mismo tiempo como capacidad lingüística de producir infinitos discursos gramaticalmente conformes y como capacidad social que permite usar adecuadamente esta competencia en una situación determinada; por otro, las estructuras del mercado lingüístico que se imponen como un sistema de sanciones de censuras específicas (Bourdieu, Significa 12).

Se trata, pues de una relación entre habitus y el mercado (ibid.). Los habitus se definen como

sistemas de disposiciones duraderas y transponibles, estructuras estructuradas predispuestas a funcionar como estructuras estructurantes, es decir, en tanto que principios generadores y organizadores de prácticas y representaciones que pueden estar objetivamente adaptadas a su fin sin suponer la búsqueda 
consciente de fines y el dominio expreso de las operaciones necesarias para conseguirlos, objetivamente 'reguladas' y 'regulares' sin ser para nada el producto de la obediencia a reglas, y siendo todo esto, objetivamente orquestadas sin ser el producto de la acción organizadora de un jefe de orquesta (Bourdieu, Sentido 92).

Como la cultura, son "formas específicas, socialmente sancionadas de hacer las cosas" (Bernández, Significa 268), en este caso, en relación al lenguaje.

En definitiva, como la polarización advertida más arriba, entre el ser y el no-ser, entre lo que es, lo que se dice que es, y lo que no es o lo que se dice que no es o no puede ser, que caracteriza ontológicamente la filosofía griega con Parménides y cuyo sentido se descubre en Platón, Aristóteles, Epicuro y los estoicos (Dussel, Filosofía 17), la polarización que presenta el mercado lingüístico, imbuido de toda la estructura social, nos sitúa ante discursos legítimos (legitimados)/discursos ilegítimos (no legitimados), ante una lengua legítima y una lengua no legítima (cf. Bourdieu, Significa 20, 23, 33).

Las ideologías lingüísticas no son exclusivas de un grupo (Lippi-Green English), del grupo dominante, sino que atraviesan toda la estructura social y suponen representaciones socialmente compartidas sobre el lenguaje, sus usos, los hablantes y sus grupos, con relación a un mercado que queda definido, como hemos visto, según la relación del habitus, los intercambios lingüísticos y los precios que adquieren los discursos que circulan en él. Las ideologías lingüísticas se incorporan en el habitus y afectan a los precios y la expectativa de beneficio social, que, a su vez, refuerzan las mismas ideologías linguiísticas. Cuestión diferente es que la imposición de una ideología lingüística sea más efectiva y eficaz para el grupo que tiene los medios adecuados para tal imposición: a saber, la escuela, los medios de comunicación, etc. Por lo tanto, en el ámbito de la dominación, son los grupos dominantes los que imponen su ideología lingüística, que responde a aquel esquema social del sistema-mundo y a la manera en que se construye el conocimiento. Tal imposición se lleva a cabo a través de las instituciones sociales señaladas, incluyendo la familia (Bourdieu Significa: 44).

\section{El capital simbólico andaluz como zona del no-ser}

Un mercado lingüístico donde unos hablantes son descapitalizados en determinados campos simbólicos, como el mediático, se da al interior de la Península Ibérica, en España. Los andaluces, habitantes de la comunidad autónoma más poblada 
del Estado español (8,4 millones, según el INE; casi un 20\% del total), situada en el sur peninsular, son un buen ejemplo de hablantes descapitalizados lingüísticamente, en un mercado que impone sus precios desde una lógica castellanocéntrica. Esta lógica es jerarquizadora, donde los capitales simbólicos que adquieren más valor son los correspondientes a la lengua legitimada y que corresponde con el centro de poder político, económico y militar del Estado: Madrid, que históricamente representa en esencia a Castilla. Andalucía supone la otra cara de la moneda: el valor de su capital simbólico es desvalorizado. Esta situación nos muestra claramente una zona del ser, una línea abismal y una zona del no-ser, zonas y línea que son simbólicas y claramente ligadas a estos capitales simbólicos.

La incorporación de Grosfoguel (Concepto, Retos, Racismo) a nuestra teoría nos facilita la compresión de un problema visto con perspectiva histórica. Grosfoguel retrotrae "el encubrimiento del Otro" del que habla Dussel (Encubrimiento) en relación con los pueblos amerindios y afroamericanos (ya sea de Norteamérica, el Caribe o América del Sur) hasta la conquista castellana del sur de la Península Ibérica, como ya adelantamos más arriba. En la Conquista, muestra acertadamente Grosfoguel, se llevaron a cabo las prácticas de inferiorización del Otro, que, según sostenemos, son visibles hoy en la desvalorización de los capitales simbólicos linguiísticos y culturales del sur peninsular por parte de esa lógica de poder, que funciona tanto a nivel micro como macro, pues, también lo indica Grosfoguel, cualquier práctica de inferiorización precisa de una institucionalización. Cuando decimos "poder" no decimos el poder del Estado, tal y como éste lo concibe, por ejemplo, en sus normas jurídicas. De acuerdo con Foucault (Microfísica 158), "el poder se construye y funciona a partir de poderes, de multitud de cuestiones y de efectos de poder", de tal modo que "para que el Estado funcione como funciona es necesario que haya [...] relaciones de dominación bien específicas que tienen su configuración propia y su relativa autonomía", al menos, en relación a los Estados modernos europeos o europeizantes. Es con el concepto de micropoder al que apunta Foucault con el que trabajamos: el de las relaciones interpersonales e intergrupales, hasta conectarlas, en nuestro análisis, con la jerarquía de dominación de la que habla F. Fanon, denunciando la situación colonial afrocaribeña, llama "racismo":

Para Fanon, el racismo es una jerarquía global de superioridad e inferiodad sobre la línea de lo humano que ha sido políticamente producida y reproducida como 
estructura de dominación durante siglos por el «sistema imperialista/occidentalocéntrico/cristianocéntrico/capitalista/patriarcal/moderno/ colonial» (Grosfoguel, Racismo 93).

En definitiva, se trata de una jerarquía global, interseccional (Grosfoguel, Racismo 94), incluyendo el conjunto de los saberes y sus marcos categoriales:

El racismo epistémico se refiere a una jerarquía de dominación colonial donde los conocimientos producidos por los sujetos occidentales (imperiales y oprimidos) dentro de la zona del ser se consideran a priori como superiores a los conocimientos producidos por los sujetos coloniales no-occidentales en la zona del no-ser (Grosfoguel, Racismo 98).

El uso de "racismo" no ha de ser problemático, ya que lo verdaderamente problemático es la invención de "raza" por parte de los ilustrados franceses, como es el caso del naturalista Leclerc, en cuya Histoire naturelle de l'homme de 1749 (traducida al castellano en 1834) se clasifica por primera vez al ser humano en "razas" (el blanco, superior; el negro y el amarillo, inferiores) (cf. Leclerc, Obras: 199), dando nacimiento a este sentido en la palabra raza desde entonces, algo que a finales del siglo XX la genética ha echado por tierra (Cavalli-Sforza Genes), por resultar falsas tanto la clasificación como el propio concepto de raza. Lo que nos interesa es destacar cómo, a partir de unas prácticas sociales determinadas, se conforma una ideología, que se toma a sí misma muy en serio -los racistas creen dogmáticamente en sus propias ideas y, como vemos, pueden hacerlas pasar por ciencia-, contribuyendo, a su vez, mediante la institucionalización epistémica, a reproducir tal ideología y a justificar tales prácticas, que así se ven reforzadas.

Desde un planteamiento similar al de Grosfoguel al denunciar el "racismo epistémico" (Racismo 98), Boaventura de Sousa Santos (con sus Epistemologías del Sur -que buscan igualmente la descolonización de los saberes-) aboga por una "justicia cognitiva" para "una justicia social" (Descolonizar 12), comenzando por "la identificación de las relaciones desiguales de poder-saber que subyacen a las epistemologías del Norte", que supone "un primer paso para transformar esas relaciones de poder" (ibid., p. 13).

El capital simbólico discursivo de los andaluces supone, en este marco teorético fanoniano, una zona del no-ser frente a la zona del ser del centro-norte peninsular. Esto supone una síntesis histórica, filosófica, sociológica y política de las causas a las que 
atiende el valor del mercado lingüístico español, en el que se privilegian unos capitales sobre otros, en determinados campos simbólicos, de tal manera que este mismo valor de los capitales simbólicos responde a una ideología de dominación, desigualdad e inferiorización, con la lengua -en este caso- como marcador. Ello tiene importantes repercusiones desde el punto de vista de la justicia social, que vendría representada, en contraposición con aquella ideología jerarquizadora, por una ideología horizontal, una ideología de la igualdad y la justicia social.

\section{Repercusiones de la desvalorización: injusticia social.}

A continuación, se presentan algunos testimonios de andaluces en los que se da cuenta de la desvalorización, la discriminación, los prejuicios culturales y/o lingüísticos, y hasta acoso, siempre por la condición de ser hablantes andaluces. Como se verá, algunos de estos testimonios apuntan a situaciones en las que las consecuencias son de carácter socioeconómico (Rodríguez Iglesias Prejuicio), concretamente en el campo laboral.

Los testimonios fueron recogidos mediante encuestas ${ }^{9}$, lo que nos obliga a una aclaración. Somos de la opinión de Bourdieu de que "lo que registra la encuesta cultural o lingüística no es una manifestación directa de la competencia, sino un producto complejo de la relación entre una competencia y un mercado, un producto que no existe fuera de esta relación" (Mercado 151), por lo que "no es posible pensar en una situación de encuesta «limpia» de cualquier efecto de dominación". Sin embargo, usamos la encuesta dentro de un contexto de investigación muy específico: conocer a hablantes con anécdotas relacionadas con las situaciones de desvalorización de sus capitales por parte de miembros de otros grupos (o del mismo grupo) para una posterior investigación etnográfica con los sujetos-agentes que dieran cuenta de tal situación. La encuesta no malversa, en nuestra opinión, el objetivo, pues de lo que quiere dar cuenta no es de cómo ven sus prácticas discursivas estos sujetos-agentes -mediatizados por una serie de preguntas enclaustradas-, sino de qué les ha sucedido con otros sujetos-agentes en relación con su habla. No obstante, se incorpora un testimonio recogido fuera de encuesta por una de las informantes (el segundo de I.4).

\footnotetext{
${ }^{9}$ Las encuestas se hicieron en el marco de un trabajo de posgrado dirigido por la profesora Celia Casado Fresnillo, UNED.
} 
Las encuestas se hicieron a través de Formularios de Google, una aplicación software en línea que permite, además de confeccionar encuestas, registrar los datos automáticamente en un documento Excel y obtener gráficos. Una vez confeccionada, se contactó con personas de cuyas experiencias ya teníamos información, por contactos precedentes. Estos informantes hicieron de enlace, a su vez, entre el investigador y otros nuevos informantes. La encuesta fue remitida por el investigador a través de comunicación privada, esto es, que no estaba abierta a cualquier persona que quisiera participar sin conocimiento del investigador, ya que éste necesitaba conocer si la persona cumplía los requisitos para su participación, velando por la calidad de los datos.

A todos se les interrogó acerca de sus experiencias con miembros de otro grupo que hubieran desvalorizado su habla andaluza, con diferentes tipos de preguntas: cerradas y abiertas. Estas últimas tuvieron un gran peso, ya que daba libertad a los encuestados para expresar sus experiencias, sin ser dirigidos. En este sentido, se evitaron preguntas cerradas del tipo: “¿Crees que en el norte se discrimina a los andaluces?” o ¿crees que el andaluz habla peor que el castellano?”. En su defecto, se generó un sistema de preguntas que evitaba dirigir al encuestado, pero en el que introdujeron ciertas preguntas de control. Es el caso de una de las últimas preguntas en la encuesta: tras interrogar acerca de prejuicios, discriminación, etc., se pregunta explícitamente: “¿Existen los prejuicios lingüísticos?”. Con esto se pretendía evaluar y poner en contexto las palabras de la persona encuestada, ya que hay casos en los que considera el/la informante que no ha sentido discriminación, pero sí habla de burlas por su habla y niega que existan prejuicios.

Hubo dos momentos en nuestra interpretación de los datos: la puramente estadística, derivada de la encuesta, y la interpretativa, donde se transforman los datos cuantitativos en cualitativos, que son los que más nos interesan. Los datos estadísticos no pueden ser concluyentes, ya que una gran parte de la información obtenida -excepto la estrictamente objetiva, como la edad, el sexo, la formación- está basada en las percepciones de los propios hablantes. Otra parte de los datos nos dirá mucho, poco o nada -según lo que han aportado y compartido de sus experiencias- acerca de lo vivido con relación a la discriminación por la que se les pregunta.

Un problema a tener en cuenta estrechamente relacionado con esto último ha sido la postura subjetiva de cada individuo respecto de los conceptos de prejuicio y 
discriminación, incluso, a la luz de las muestras obtenidas, de qué entiende cada informante por lengua, pues esto está, a su vez, estrechamente relacionado con su valoración de las variedades y su ideología lingüística.

El número total de participantes ha sido de 37, un número muy superior con el que se trabaja en sociolingüística cualitativa, que, por otro lado, rehúsa la encuesta a favor de la entrevista y la observación participante. En la sociolingüística cuantitativa se da especial relevancia al número de informantes, pues se busca medir el fenómeno con relación a un segmento de la población que sea representativo de la totalidad, como en los trabajos de W. Labov (Social) o H. López Morales (Estratificación). Sin embargo, en la sociolingüística cualitativa no lo es, como ponen de manifiesto los trabajos de Relaño y Solano (Vivencia) y Sabaté Dalmau (Inmigración). Aquí, no queremos medir y no es relevante si la situación de opresión la padece un $0,025 \%$ de la población o un 25\%. A pesar de la dificultad que pueda entrañar este número para su manejo en investigación cualitativa, en nuestro caso sólo se trataba de conocer situaciones de opresión y microagresiones lingüísticas, para futuras investigaciones con entrevistas, donde el número deberá ser más reducido.

Estos son los datos generales de la encuesta: la edad de nuestros informantes oscila entre los 22 y los 56; respecto del sexo, diecisiete son mujeres (46\%) y 20 son hombres (54\%); un 8\% con Educación Secudanria Obligatoria, un 5\% con Bachillerato, un $11 \%$ con Formación Profesional Básica, un 14\% con Formación Profesional Superior, un $46 \%$ con licenciatura universitaria, un $16 \%$ con máster y un $3 \%$ con doctorado. Se interrogó a nuestros informantes acerca de si habían residido fuera de Andalucía y, en su caso, en qué lugar. Está bastante equilibrado el número, inclinándose la balanza ligeramente hacia los que residen o han residido fuera de esta comunidad autónoma: Sí, un 51\%; no, un 49\%. A continuación indicamos los lugares seguidos del número asignado al/a la informante: Burgos (3) / Cantabria (4) / Argelia (8) / Madrid (9) / Madrid y París (11) / Madrid (12) / Burgos y Galicia (17) / Murcia (20) / Madrid y Francia ( 21) / EE.UU., Perú y Barcelona (23) / Ávila (26) / Roma, Palermo y Florencia (27) / Galicia (28) / Alicante y Barcelona (29) / Madrid, Barcelona y Eslovenia (30) / Cuba, Galicia, Cataluña, Baleares, Portugal e Italia (31).

A los informantes se les ha preguntado explícitamente si hablan la variedad andaluza, especificándoles "acento andaluz", por ser esta etiqueta la manera más usual 
entre los hablantes de identificar tal variedad. Sorprendentemente, tres informantes declararon no hablar en andaluz, por lo que se procedió a valorar sus respuestas para evaluar si su declaración respecto del "acento andaluz" era constitutiva de una ideología lingüística al respecto. No se pudo concluir de manera exacta, pues no se aportaban datos suficientes. He aquí uno de los problemas que plantea la encuesta frente a la entrevista, especialmente, si no hay interacción con la persona encuestada. Estos tres informantes, un $8 \%$ del total, fueron descartados de nuestro estudio.

A partir de aquí, mediante pregunta abierta, se pide a los informantes que den cuenta de alguna posible situación de discriminación. En concreto, se pregunta: “¿Has sufrido algún tipo de discriminación por tu habla fuera de Andalucía? Cuéntanos tu/s experiencia/s en las líneas que precises para ello". Que sea pregunta abierta permite al informante mayor libertad, dando al investigador más información de la que se obtendría con preguntas cerradas: en primer lugar, permite valorar las percepciones; en segundo lugar, el investigador accede directamente a historias vividas por los propios informantes, constituyendo un material de un valor, sin duda, incalculable. Además, se suplen las limitaciones de la encuesta.

A continuación se presentan aquí fragmentos de las respuestas que contestan a la referida pregunta, así como a las preguntas de control, señaladas más arriba.

Los testimonios, ya adelantados en Rodríguez Iglesias (Hybris y Conferencia), aparecen aquí numerados por el número de informante [I seguido del número] y se añade a la I.4 un testimonio de importante valor recogido fuera de encuesta, a petición de esta informante.

[I.3] "En Castilla, se me dijo que, a pesar de mi formación, no sabía hablar correctamente porqué me comía las eses finales y que seguro escribía con faltas de ortografía. Ante mi respuesta de que no era posible se me dijo: «seguro que alguna se te escapa»".

Este informante (I.3) es periodista y tiene una formación de licenciatura y máster. Es patente, dado su trabajo de carácter público, que no tiene dificultades con la ortografía. Pero sus interlocutores no tuvieron la intención de comprobarlo o, al menos, tener la prudencia de no valorar sin conocer los hechos. Dan por sentado que al ser andaluz, nuestro informante cometerá faltas de ortografía. En nada ha ayudado que un libro de referencia sobre la historia del andaluz publicado por una editorial prestigiosa y 
un profesor de reconocida trayectoria, J. A. Frago Gracia, contenga dislates como este: "Nada de particular tiene que para un andaluz, un canario o un cubano, pongo por caso, sea más difícil que para un burgalés o un zaragozano de similar formación escolar atenerse a la práctica "oficial" que en la escritura rige el uso de la s y de c-z, de -r y -1 o de la -s" (Frago Gracia 33), por mucho que sus únicas pruebas sean las notas de un frutero y de un albañil o una decena de crónicas de toros, fútbol y vida social del ABC de Sevilla de principios de la década de 1980.

[I.4] "Con siete años viví en Cantabria. A mi hermano y a mí nos acorralaban en el patio del colegio y nos llamaban gitanos".

Esta hablante es profesora de inglés, andaluza. Parece que su identificación como tal la llevó a asociarla a una etnia que convive con otras en España y sobre la que también hay prejuicios y situaciones de discriminación, como la relatada, pues, con independencia de si es gitana o no, era identificada como tal o sometida a igual vejación. Fuera de encuesta el informante 3 refiere un suceso similar en la ciudad en la que éste residió en su infancia.

[I.4] "El martes [16 de junio de 2015] una profesora de la Universidad del País Vasco me dijo que cómo podía ser yo profesora de inglés, siendo andaluza y teniendo este acento".

La misma informante I.4 añadió fuera de encuesta cómo ha sido puesta en cuestión como profesora de inglés sólo por ser andaluza. Su prejudicadora, según relata, ni siquiera conoce si habla o no inglés y qué conocimientos específicos tiene sobre el mismo.

[I.9] "La mayoría de las veces en el trabajo [en Madrid]. Comentarios como: «aprende a hablar, paleto» y demás".

Este informante es un camarógrafo de televisión. Vive en Madrid desde los 18 años. Valora esas agresiones lingüísticas como "burlas". No lo ponen en cuestión con respecto a su desempeño profesional, dado que su trabajo no está relacionado con la voz, pero sí lo inferioriza respecto de los miembros del grupo de dominio, que consideran que no sabe hablar y debe aprender a hacerlo, al identificarlo como andaluz. 
[I.15] "Un comentario en el que nos acusaban a los andaluces de hablar con bajeza o no saber hablar. Venía de un grupo de catalanes".

Esta hablante, trabajadora del sistema de salud, relata la experiencia con miembros de otro grupo que la inferiorizan al considerar, como en tantos otros casos que estamos viendo, que al ser andaluza no sabe hablar.

[I.17] "Creen que los andaluces no sabemos hablar y dicen que no nos entienden".

Esta informante también da cuenta de esta situación de discriminación que desvaloriza no sólo el capital simbólico de estos sujetos, sino también su ontología. Son los excluidos de los que habla Dussel (Ética 20), al no ser tratados como iguales: cuando hablan no se les escucha, no se les quiere entender.

[I.19] "Como periodista tendría que esconder mi acento fuera de Andalucía. Así lo imponen".

Esta informante es periodista. Trabajaba en televisión en el momento de la entrevista. Hoy en día está en situación de desempleo y como en la encuesta relata, según denuncia, la descartan de las ofertas laborales de su profesión por carecer de los capitales lingüísticos legitimados por el grupo que ostenta la hegemonía (cf. Gramsci 248) y que se encuentra en una situación de privilegio social y lingüístico (véase Rodríguez-Iglesias Conferencia e Interseccionalidad).

[I.23] "En Alicante [...] salió la conversación del tema de Andalucía, que la gente es vaga, que no trabaja, que no sabe hablar bien e, incluso, llegó a preguntarme si yo sabía escribir bien en castellano".

La opresión linguiística está interseccionada con otras formas de opresión: estamos apuntando a la ontológica, seres inferiorizados en general. Esta idea de la interseccionalidad es una aportación de los feminismos negros norteamericanos, en concreto de K. Crenshaw (Mapping), que, como otras investigadoras sobre la opresión de las mujeres negras en Estados Unidos, pone de relieve cómo las diferentes opresiones funcionan de manera interseccionada respecto de los marcadores de sexo, piel, etc. (véase Rodríguez-Iglesias Interseccionalidad). 
[I.26] "En Ávila se metían tanto con mi acento andaluz que decían que no se nos entendía nada, que nos debían enseñar a hablar castellano neutro en la escuela. [...] Tuve que aguantar muchos comentarios en plan: «Claro, es normal que seáis la Comunidad con más paro, ¿quién va a querer a gente que habla tan mal?». Entre otras muchas cosas".

Este testimonio apunta a la misma cuestión que hemos comentado, pero pone sobre la mesa un pseudoconcepto fundamental para el funcionamiento de la opresión: el acento neutro, cosa que no existe, pues todo ser humano vive en una espacialidad. Esta cuestión la trabaja desde el punto de vista ontológico el filósofo colombiano Santiago Castro-Gómez en lo que él ha llamado "la hybris del punto cero" (Castro-Gómez) y que me ha servido a mí para dar cuenta de estas cuestiones usando su terminología en lo que yo he llamado "la hybris del punto cero metalingüístico": la soberbia de desconocer la espacialidad, decirse "neutro", en este caso, decir que se habla con acento neutro o -he aquí otra fórmula de ese proceder- con una forma estándar, cosa que es imposible, pues es constitutiva de la escritura y no de la lengua hablada (Penny 292). En febrero de 2016, el diario español El País me preguntó para uno de sus reportajes (El País) acerca de esta cuestión, a partir de los testimonios de diferentes actores de cine y teatro, cuyos testimonios atestiguaban cómo se les obliga a hablar como si fueran castellanos en papeles que, en principio, no requiere una identificación del personaje como oriundo de Madrid o Salamanca.

[I. 26] "Siendo periodista, en el resto de España no está bien visto el acento andaluz, sobre todo para las radios y las televisiones. O tienes un acento más neutro, aun siendo andaluz o ellos mismos te indican que debes corregir tu acento, algo que no comprendo, cuando a los canarios, catalanes y gallegos sí les dejan su acento en los medios".

Tenemos aquí a otro periodista, que se expresa en los mismo términos que la informante 19. Da cuenta de una situación generalizada, especialmente en los medios audiovisuales, en los que estos hablantes generalmente han de ocultar su variedad y usar la del grupo de dominio. La informante 36 también ratifica esta situación:

[I.36] "Soy periodista y fuera de nuestra Comunidad el andaluz no gusta en los medios. Hay prejuicios".

La siguiente informante es profesora universitaria en la actualidad. Anteriormente, buscando empleo en Italia fue descartada para trabajar en el Instituto 
Cervantes por ser andaluza al darse preferencia a profesores/as del centro y norte peninsular español, según su testimonio:

[I.27] "Tanto en España como en Italia, a la hora de la búsqueda de empleo, me ha ocurrido que han desestimado mi currículum en academias donde se imparte ELE, porque daban preferencia a personas que no fueran andaluzas".

La situación puede llegar a extremos surrealistas como el que sigue:

[I. 28] "Me han llegado a decir trabajando en un banco de alimentos gallego y hablando andaluz que la gente podría pensar que era broma, que crease desconfianza y no me tomasen en serio".

Este testimonio no hace sino confirmar todo el análisis que estamos haciendo respecto de cómo se pone en cuestión al ser humano a partir de un marcador, la lengua, en nuestro caso, aunque también deberíamos añadir el origen geográfico y cultural con el que se asocia.

Los dos últimos testimonios redundan en la cuestión que hemos visto en otros informantes.

[I.34] "A amigos de otra Comunidad les parece gracioso el andaluz en sentido despectivo".

[I.36] "Sobre todo los cántabros, se reían mucho de nuestro acento y me decían que no sabíamos hablar".

Estos informantes, a través de sus testimonios, dan cuenta de cómo son puestos en cuestión respecto de sus capitales simbólicos, en concreto, respecto de sus capitales lingüísticos. Son descapitalizados. La lógica de una jerarquización de la lengua legítima frente a la ilegítima, basada en la desigualdad, conlleva la descapitalización del hablante, cuyos capitales simbólicos son inferiorizados, deslegitimados, apartados, en diversos grados y según el campo práctico.

La existencia de prejuicios lingüísticos supone que sólo los discursos que se adaptan a determinadas normas, géneros, registros y sociolectos, son considerados adecuados en contextos sociales relevantes [...], mientras los que no se adaptan a estas normas [...] se encuentran de partida deslegitimados y son considerados como no pertinentes en el contexto en el que son producidos, indica Martín Rojo, que sigue: "Por ello, la regulación discursiva de los distintos contextos sociales constituye un poderoso mecanismo de exclusión, por el cual se excluye lo que se dice y a quien lo dice, sobre la base de cómo lo dice" (Martín Rojo, Orden 24). 
Hay un exceso ontológico, de hablantes que se imponen sobre estos otros hablantes, que los cuestionan, que desconociendo su espacialidad teorizan desde una supuesta superioridad y llevan a cabo una praxis inferiorizadora. De lo que da cuenta esta situación es del privilegio social y lingüístico de esos grupos respecto de este grupo, el andaluz, sometido a una situación de dominio, deslegitimación, desvalorización y descapitalización.

\section{Conclusión}

Es evidente que existe una relación de fuerza, de dominación, entre un grupo (o unos grupos) y otro(s). En esta evidencia, el grupo humano constituido por los andaluces se ve desvalorizado frente a otro grupo, cuyos capitales simbólicos tiene un valor específico en el conjunto del mercado lingüístico que suponen los intercambios discursivos.

Supone una injusticia social, en tanto que, como la piel, el sexo y otros factores sociales, la lengua es un elemento característico de los sujetos-agentes, de los miembros de los grupos humanos, que interaccionan socialmente casi exclusivamente a través de los intercambios lingüísticos, es decir, en mercados lingüísticos. Que una persona o un conjunto de personas se vean inferiorizadas por cualquiera de estos rasgos, además de injusto, es un acto racista, entendiendo por racismo cualquier acto de inferiorización de carácter cultural, incluyendo el mismo lenguaje, y que, como hemos visto con Fanon y Grosfoguel, forma parte de una jerarquía de inferiorización global que funciona interseccionalmente a través de diferentes marcadores, citados arriba.

Poder ver el problema de desvalorización de los capitales simbólicos lingüísticos (y no lingüísticos) andaluces en el marco de una ideología global de inferiorización nos permite trabajar desde una misma posición y un marco teórico transmoderno, en el sentido dusseliano, de descolonización de los saberes (como apunta B. de Sousa Santos y la red modernidad/colonialidad en Latinoamérica), para un completo replanteamiento epistemológico que, con y por la justicia cognitiva, reinterprete con nuevas categorías realidades malinterpretadas a partir de prácticas de dominación e inferiorización que se ven a su vez comprometidas (tanto las descripciones que aspiran a ser científicas como las realidades mismas). 


\section{Bibliográfia}

--------. Pragmática y declaración sobre los moriscos esclavos que fueron tomados en el Reyno de Granada y la orden que con ellos se ha de tener. Madrid: Alonso Gómez, 1573. Impreso.

Alvar, Manuel. Lengua y sociedad. Barcelona: Planeta, 1976. Impreso.

Alvar, Manuel. Hombre, etnia, estado. Madrid: Gredos, 1986. Impreso.

Arias Montano, Benito. De varia Republica, sive Commentaria in librum Judicum, 1592. Impreso.

Blommaert, Jan. "Sociolinguistics". The Routledge Handbook of English Language

Studies. Ed. C. Leung y B. Street. Londres: Routledge, 2014. p. 131-144. Impreso.

Blommaert, Jan y Ben Rampton. "Language and Superdiversity: A position paper”. Working Papers in Urban Language \& Literacies Paper 70 (2011). Impreso.

Blommaert, Jan y Jef Verschueren. "The role of language in European nationalist ideologies". Pragmatics 2:3 (1992): 355-375. Impreso.

Bourdieu, Pierre. El sentido práctico. Madrid: Taurus, 1991. Impreso.

Bourdieu, Pierre. "El mercado lingüístico". Sociología y cultura. México: Grijalbo, Conaculta, (2002): 143-158. Impreso.

Bourdieu, Pierre. Qué significa hablar. Economía de los intercambios lingüísticos. Madrid: Akal, 2008. Impreso.

Bourdieu, Pierre y Jean-Claude Passeron. Los herederos. Los estudiantes y la cultura. Buenos Aires: Siglo XXI, 2009. Impreso.

Carbonero, Pedro. Estudios de Sociolingüística Andaluza. Sevilla: Secretariado de Publicaciones de la Universidad de Sevilla, 2003. Impreso.

Castro-Gómez, Santiago. La hybris del punto cero: ciencia, raza e ilustración en la Nueva Granada (1750-1816). Bogotá: Editorial Pontificia Universidad Javeriana, 2005. Impreso.

Cavalli-Sforza, Luigi Luca. “Genes, pueblos y lenguas”. Investigación y Ciencia, 1992. Impreso.

Colón, Cristóbal. Diario de abordo. Luis Arranz (ed.). Madrid: Edaf, 2006. Impreso.

Coseriu, Eugenio. Lecciones de lingüística general. Madrid: Gredos, 1999. Impreso.

Crenshaw, Kimberlé. "Mapping the margins: Intersectionality, Identity Politics, and Violence Impreso.against Women of Color". Stanford Law Review v. 43, n.6, (1991): 1241-1299. Impreso.

Cruz Artacho, Salvador. Andaluces contra el caciquismo. Sevilla: Centro de Estudios Históricos, 2012. Impreso.

Dussel, Enrique. 1492. El encubrimiento del Otro. Hacia el origen del "mito de la Modernidad. La Paz: Plural Editores-Centro para el Desarrollo-CID, 1994. Impreso.

Dussel, Enrique. Filosofía de la liberación, Bogotá: Nueva América, 1996. Impreso.

Dussel, Enrique. "Sobre el sujeto y la intersubjetividad: el agente histórico como actor en los movimientos sociales". Revista Pasos n. 84 Segunda Época JulioAgosto (1999). Impreso.

Dussel, Enrique. Política de la liberación. Historia mundial y crítica. Madrid: Editorial Trotta, 2007. Impreso.

Dussel, Enrique. La ética de la liberación: ante el desafío de Apel, Taylor y Vattimo con respuesta crítica inédita de K.-O. Apel. México: Universidad Autónoma del Estado de México, 1998. Impreso. 
El País. "La cuestión del acento neutro". Diario El País. 28 de febrero de 2016. Impreso.

Escobar, Arturo. Más allá del Tercer Mundo. Globalización y diferencia. Bogotá: Instituto Colombiano de Antropología e Historia, 2005. Impreso.

Espinosa Miñoso, Yuderkis, Diana Gómez Correal y Karina Ochoa Muñoz (eds.). Tejiendo de otro modo: Feminismo, epistemología y apuestas descoloniales en Abya Yala. Popayán: Editorial Universidad del Cauca, 2014. Impreso.

Fairclough, Norman. Language and power. Essex/Nueva York: Longman, 1989. Impreso.

Fanjul, Serafín. La quimera de Al-Andalus. Madrid: Siglo XXI, 2004. Impreso.

Fernández, Mauro. "Los orígenes de la Sociolingüística". II Jornadas de Lingüística, (1996): 105-132. Impreso.

Foucault, Michel. Microfísica del poder. Madrid: Ediciones La Piqueta, 1979. Impreso.

Foucault, Michel. Vigilar y castigar. Buenos Aires: Siglo XXI, 2002. Impreso.

Foucault, Michel. Hay que defender la sociedad. Madrid: Akal, 2003. Impreso.

Frago Gracia, Juan Antonio. Historia de las hablas andaluzas. Madrid: Arco Libros, 1993. Impreso.

Gramsci, Antonio. Prison Notebooks. Volume I. Nueva York: Columbia University Press, 1999. Impreso.

Grosfoguel, Ramón. "El concepto de «racismo» en Michel Foucault y Frantz Fanon: ¿teorizar desde la zona del ser o desde la zona del no-ser?". Tabula Rasa n.16 (2012): 79-102. Impreso.

Grosfoguel, Ramón. "Retos de los estudios étnicos en Estados Unidos en el sistema universitario global occidentalizado: entre el multiculturalismo liberal, las políticas identitarias, la colonización disciplinas académicas y las epistemologías decoloniales". Relaciones Internacionales, núm. 19, febrero ( 2012): 13-26. Impreso.

Grosfoguel, Ramón. "Racismo/sexismo epistémico, universidades occidentalizadas y los cuatro genocidios/epistemicidios del largo siglo XVI". Tabula Rasa n.19 (2013): 31-58. Impreso.

Hamel, Rainer Enrique. "Conflicto entre lenguas, discursos y culturas en el México indígena: los procesos de desplazamiento lingüístico". Palavra, 11 (2003): 6388. Impreso.

Jackson, Gabriel. La República española y la guerra civil: 1931-1939. Barcelona: Crítica, 1999. Impreso.

Joseph, J. E. y T. J. Taylor (eds.). Ideologies of language. Londres/Nueva York: Routledge. 1990. Impreso.

Labov, William. The Social Stratification of English in New York City. Cambrigde: Cambridge University Press, 2006. Edición original, 1966. Impreso.

Lander, E. "¿Conocimiento para qué? ¿Conocimiento para quién? Reflexiones sobre la universidad y la geopolítica de los saberes hegemónicos". Revista Venezolana de Economía y Ciencias Sociales. V. 1 6, n. 2, mayo-agosto (2000,): 53-72. Impreso.

Leclerc, G.-L. Obras completas de Buffon. Historia del hombre, tomo II, Barcelona: Imp. de A. Bergnes y $C^{\text {a }}$, 1834. Impreso.

Lippi-Green, Rosina. English with an Accent Language, ideology, and discrimination in the United States. Londres/Nueva York: Routledge. 1997. Impreso.

López Morales, Humberto. Estratificación social del español de San Juan de Puerto Rico. México: UNAM, 1983. Impreso. 
Maldonado-Torres, Nelson. "On the coloniality of being". Cultural Studies, v.21, n. 2, (2007):240-270. Impreso.

Martín Rojo, Luisa. Constructing Inequality in Multilingual Classrooms, Berlín/Nueva York: De Gruyter Mouton, 2010. Impreso.

Moreno, Isidoro. La identidad cultural de Andalucía. Sevilla: Centro de Estudios Andaluces, 2008. Impreso.

Moreno Cabrera, Juan Carlos. El nacionalismo lingüístico. Una ideología destructiva. Barcelona: Península, 2008. Impreso.

Ortega y Gasset, José. "Teoría de Andalucía”. La identidad cultural de Andalucía: aproximaciones, mixtificaciones y evidencias. Isidoro Moreno (ed.) Sevilla: Centro de Estudios Andaluces, 2008. Impreso.

Penny, Ralph. Variación y cambio en español. Madrid: Gredos, 2004.Impreso.

Pujolar Cos, Joan. "La sociolingüística crítica". Sociolingüística. Ed. M. Puigdevall, R. Casesnoves, J. Conill, E. Codó, y J. Pujolar Cos. Barcelona: Editorial UOC, 2012. Impreso.

Relaño Pastor, Ana María y Rosa María Soriano Miras. "La vivencia del idioma en mujeres migrantes. Mexicanas en Estados Unidos y marroquíes en España". Migraciones Internacionales, julio-diciembre, año/vol. 3, número 004 (2006), 85-117. Impreso.

Rivera Cusicanqui, Silvia. Violencias (re) encubiertas en Bolivia. La Paz: La Mirada Salvaje/Editorial Piedra Rota, 2010. Impreso.

Rodríguez-Iglesias, Ígor. “Generalización diastrática y restricción diafásica en variación diatópica”. Estudios de lingüística: investigaciones, propuestas y aplicaciones. Ed. Adrián Cabedo Nebot, Manuel Jesús Aguilar Ruiz y Elena López-Navarro Vidal. Valencia: Universitat de València, (2013): 581-593. Impreso.

Rodríguez-Iglesias, Ígor. "Prejuicios lingüísticos como condicionantes del desarrollo socioeconómico". I Simposium Internacional EDiSo 'Estudios de Discurso y Sociedad'. Universidad de Sevilla, 15 - 16 de mayo, 2014. Impreso.

Rodríguez-Iglesias, Ígor. "La 'hybris del punto cero' metalingüístico sobre el valor indexical: la lengua como marcador de la heterojerarquía de dominación". Otros Logos. Revista de Estudios Críticos, 6 (2015): 91-115. Impreso.

Rodríguez-Iglesias, Ígor. "Conferencia inaugural: la hybris del punto cero metalingüístico. Andalucía como no-Ser". VIII Encuentro de la Sociedad para el Estudio del Andaluz. Málaga: ZEA, (2016): 9-36. Impreso.

Rodríguez-Iglesias, Ígor. "Interseccionalidad en una heterojerarquía de dominación: mi mujer/su mujer". Gender and Communication. Sevilla: Universidad de Sevilla. Forthcoming. Impreso.

Sabaté Dalmau, María. "Inmigración y multilingüismo: cambios en el mercado lingüístico y la categorización social de (in)migrantes en una localidad periférica de Barcelona". El valor de la diversidad (meta)lingüística: Actas del VIII congreso de Lingüística General. Antonio Moreno Sandoval (coord.), 2008. Impreso.

Salvador, Gregorio. “Las lenguas”. Cuenta y razón 126 ,2002. Impreso.

Santos, Boaventura de Sousa. Descolonizar el saber, reinventar el poder. Montevideo: Ediciones Trilce, 2009. Impreso.

Schieffelin, Bambi, Kathryn. A. Woolard y Paul V. Kroskrity (eds.). Ideologías lingüísticas. Práctica y teoría. Madrid: Catarata, 2012. Impreso.

Soria Mesa, Enrique. "Los moriscos que se quedaron. La permanencia de la población de origen islámico en la España Moderna (Reino de Granada, siglos XVIIXVIII)". Vínculos de Historia, n. 1 (2012): 205-230. Impreso. 
Swartz, David. Culture and Power. The Sociology of Pierre Bourdieu. Chicago/London: The University of Chicago Press, 1997. Impreso.

Valdés, Juan. Diálogo de la lengua. Alicante: Biblioteca Virtual Miguel de Cervantes, 2004. Edición digital a partir de la edición de E. Boehmer, Leipzig, Romanische Studien, 1895. Impreso.

Van Dijk, Teun. Ideología. Una aproximación multidisciplinaria. Barcelona: Gedisa, 1999. Impreso.

Van Dijk, Teun. Discurso y poder. Barcelona: Gedisa, 2009. Impreso.

Wallerstein, Immanuel. Después del liberalismo. México: Siglo XXI, 2001. Impreso.

Wallerstein, Immanuel. Análisis de Sistemas-Mundo. Una introducción. México: Siglo XXI, 2006. Impreso.

Weinreich, Uriel. Languages in Contact: Findings and Problems. New York: Linguistic Circle of New York, 1953. Impreso.

Wodak, Ruth. Language, power and ideology. Studies in political discourse. Amsterdam: Benjamins, 1989. Impreso.

Woolard, Kathryn. "Las ideologías lingüísticas como campo de investigación". Ideologías lingüísticas. Práctica y teoría. Ed. Bambi Schieffelin, Kathryn. A. Woolard y Paul V. Kroskrity. Madrid: Catarata, (2012): 19-70. Impreso.

Woolard, Kathryn y Bambi Schieffelin. "Language ideology". Annu. Rev. Anthropol. n. 23 (1994): 55-82. Impreso. 